\title{
(3) Biolistic transformation of Isochrysis galbana
}

[ Nature Methods

$$
\text { Glen Wheeler }^{1}, \quad \text { Rowena Stern }{ }^{1}
$$

${ }^{1}$ Marine Biological Association

Protist Research to Optimize Tools in Genetics (PROT-G)

\section{open ठaccess}

\section{DOI:}

dx.doi.org/10.17504/protocol s.io. 2 pugdnw

\section{External link:}

https://doi.org/10.1038/s415 92-020-0796-x

\section{Protocol Citation: Glen} Wheeler, Rowena Stern 2019. Biolistic transformation of Isochrysis galbana.

\section{protocols.io}

https://dx.doi.org/10.17504/p rotocols. io. 2 pugdnw

\section{MANUSCRIPT CITATION:}

License: This is an open access protocol distributed under the terms of the Creative Commons Attribution License, which permits unrestricted use, distribution, and reproduction in any medium, provided the original author and source are credited

Protocol status: Working We use this protocol and it's working

Created: May 08, 2019

Last Modified: May 08, 2019 
PROTOCOL integer ID:

22996

Keywords: Isochrysis, biolistics

\section{Preparing tungsten beads}

1 Weigh out $60 \mathrm{mg}$ tungsten into a microfuge tube

2 Wash in $1 \mathrm{~mL} 100 \%$ ethanol. Vortex. Centrifugation at 13000rpm for 1 minute then remove ethanol

3 Wash four times in $1 \mathrm{~mL}$ molecular grade water. Centrifugation at 13000rpm for 1 minute. Remove the water.

$4 \quad$ Add $1 \mathrm{~mL}$ of water to beads and transfer $50 \mu \mathrm{L}$ aliquots (whilst vortexing frequently to avoid bead sedimentation) into microfuge tubes and freeze for later use.

$5 \quad$ Add $4 \mu \mathrm{g}$ plgNAT plasmid DNA (previously prepared using Qiagen miniprep) to a $50 \mu \mathrm{L}$ aliquot of tungsten beads. The DNA volume added should not be more than $10 \mu \mathrm{L}$.

6 Add $50 \mu \mathrm{L}$ of $2.5 \mathrm{M} \mathrm{CaCl} 2$ and $20 \mu \mathrm{L}$ of $0.1 \mathrm{M}$ spermidine to the tungsten and DNA and vortex gently

7 Leave the tube for 10 minutes to sediment the beads. Centrifuge briefly for 3 seconds at 2000rpm to sediment beads. Remove supernatant.

8 Wash beads in $250 \mu \mathrm{L}$ of $100 \%$ molecular grade ethanol. Vortex and briefly centrifuge for 3 
seconds at 2000rpm. Remove the supernatant.

9 Add $50 \mu \mathrm{L}$ of $100 \%$ molecular grade ethanol. Whilst frequently vortexing to prevent sedimentation, add $10 \mu \mathrm{L}$ aliquots to individual macrocarrier discs and leave to dry.

10 Store macrocarrier discs coated in DNA-tungsten beads inside a closed Petri dish lined with Whatmann filter paper at $4^{\circ} \mathrm{C}$ until needed.

\section{Biolistic transformation}

11 Grow cultures of Isochrysis galbana for 4-7 days prior to transformation. Target cell density should be about $5 \times 10^{5}-1 \times 10^{6}$ cells $/ \mathrm{mL}$

12 Clean biolistic PDS-1000/He particle delivery system (BIORAD, CA, USA). Wipe outside and inside of the biolistic chamber with ethanol. Immerse rupture discs, macrocarrier holders and stopping screens briefly in ethanol and leave to dry

13 Connect PDS-1000 apparatus to a helium supply and a vacuum pump

14 Set up biolistic apparatus according to manufacturers instructions.

14.1 Take out rupture disc retaining cap and place rupture disc inside and place assembly back inside 
14.2 Assemble macrocarrier launch assembly. Place stopping screen onto shelf. Place macrocarrier disc in macrocarrier holder and position over stopping screen (with beads now facing downwards). Screw assembly together.

14.3 Place macrocarrier launch assembly onto the uppermost shelf of the biolistic chamber.

15 Prepare Isochrysis cells immediately prior to loading to avoid drying out. Filter $150 \mathrm{~mL}$ of $I$. galbana (NCMA 1323 from NCMA, USA) culture onto a $3 \mu \mathrm{m}$ cellulose nitrate membrane filter (diameter $47 \mathrm{~mm}$, Whatmann from GE Healthcare Life Sciences, UK)

16 Wash cells with 3-5 $\mathrm{mL}$ of biolistic loading buffer to remove excess salt. Leave filter damp so as not to dry the cells completely.

17 Transfer the filter containing cells to a small Petri dish (47 $\mathrm{mm}$ diameter).

18 Place the Petri dish onto the target plate shelf in the biolistic chamber $6 \mathrm{~cm}$ below the macrocarrier launch assembly.

19 Perform biolistic transformation process

19.1 Turn on vacuum pump and biolistic chamber.

19.2 Remove the air in the biolistic chamber by setting the vacuum button to VAC until the pressure was $27 \mathrm{in.Hg}$. 
19.3 Switch the vacuum button to hold.

19.4 Press and hold the FIRE button until the rupture disc bursts and beads have bombarded the cells.

19.5 Release the FIRE button and set the vacuum button to VENT to allow air into the chamber

20 Remove the Petri dish and replace its lid. Tungsten beads should be visible on the centre of the filter.

21 Wash the cells off the filter using $3 \mathrm{~mL} \mathrm{50 \%} \mathrm{salinity} \mathrm{F} / 2$ and place into a sterile cell culture dish.

22 Leave cells to recover overnight (16 h) in light chamber incubator

23 Count cells using a haemocytometer to determine the number of surviving cells post transformation (ideally should be similar to starting concentration). Subdivide cells into a 24 well plate, $10 \mu \mathrm{L}$ of cells per well, and make the volume in each well up to $2 \mathrm{~mL}$ with $50 \%$ salinity $\mathrm{F} / 2$ media containing $80 \mu \mathrm{g} / \mathrm{mL}$ nourseothricin. Include control wells containing non-transformed cells in media with and without nourseothricin.

24 Observe cells each week to look at cell health (motility, cell integrity). Perform cell counts in each well. If growth is observed in wells containing $80 \mu \mathrm{g} / \mathrm{mL}$ nourseothricin, take these cells and maintain on nourseothricin at $120 \mu \mathrm{g} / \mathrm{mL}$ in 24 well plates ( $2 \mathrm{~mL}$ volume) for 2 weeks and then at 
$150 \mu \mathrm{g} / \mathrm{mL}$ in $10 \mathrm{~mL}$ culture tubes for two weeks. 